\title{
IMMIGRANT INVESTORS IN FINANCIAL MARKETS: MODES OF FINANCIAL BEHAVIOR
}

\author{
Nonna KUSHNIROVICH \\ Department of Economics and Management, Economics \& Business Administration School, \\ Ruppin Academic Center, 40250, Emek Hefer, Israel \\ E-mail: nonna@ruppin.ac.il (correspondingauthor)
}

Received 06 August 2015; accepted 23 March 2016

\begin{abstract}
This study investigates the modes of financial behavior of immigrants, comparing them with native-born investors. The study developed a theoretical framework for investigating the determinants of financial behavior, combining Bourdieu's concept of economic habitus with the theories explaining behavior of investors in financial markets. Methods of clustering analysis and multinomial logit regression model were used. The study found that an investor's behavior mode is strongly predicted by determinants derived from cultural, economic and social capital. For low-income persons, the culture of origin shapes their financial behavior, and for high-income persons, their economic capital and affiliation to social class are more important. Over time, immigrants assimilate in their financial choices. This study contributes to research of financial behavior as well as migration research by explaining the factors that affect preferences for financial assets allocation among immigrants. Understanding migrants' modes of financial behavior will help policymakers to facilitate accumulation of wealth by immigrants, and in this way contribute to the process of their integration.
\end{abstract}

Keywords: immigrant investors, portfolio choice, assets allocation, risk, diversification, financial behaviour.

JEL Classification: F22, G32, G11.

\section{Introduction}

Traditional economic theory of rational choice posits that investors aspire to maximize portfolio return for a given level of risk. According to the Modern Portfolio Theory, assets diversification is a method of portfolio selection, which spreads risk over a wide range of financial assets with different levels of risk and return. In this way, diversification allows getting higher returns and reduces the portfolio's risk. Traditional economic approach of rational choice is strongly criticized by psychologists and behavioral decision scholars. They state that individual investors' portfolios are often under-diversified, and even in developed countries, the majority of households do not own stocks or hold poorly diversified portfolios (Bondt 1998; Keloharju et al. 2012). Individual household investors often act irrationally, but existing financial models of "Economic Man" ignore 
the behavioral and cultural aspects of choosing portfolios (Ahern et al. 2015; Guiso et al. 2006; Zingales 2015).

The inability of financial theories to explain why investors sometimes make irrational choices instigated the development of behavioral theories that stress the importance of investors' personal features in making investment decisions. According to Dorn and Huberman (2005), investors' personal attributes are vital to financial behavior. They distinguish between objective attributes (demographic and socio-economic characteristics) and subjective attributes (such as risk aversion and confidence), when variation in financial behavior of investors derives from the differences in these attributes. Following the Wealth Allocation Framework (Chhabra 2005), investor's risk preferences are based on his/her financial ability to take risks (an objective risk measure), and the investor's desire to avoid risk (a subjective risk measure).

The contradiction between financial and behavioral approaches may be omitted when we keep in mind that a rational choice is made by invoking the principle of expected utility, and the utility functions of individual investors are different. Investors who face the same conditions in the financial market can choose various portfolios. Utility function may express investors' cultural perceptions, personal attitudes and social norms. People are embedded in a cultural context that affects their economic and financial behavior (Pevzner et al. 2015; Zingales 2015). The literature provides some evidence of the impact of cultural and social norms on investors' decisions that result in portfolio choices (Cobb-Clark, Hildebrand 2009; Kim et al. 2012). These influences are prominent for holding investment assets such as stocks (Guiso et al. 2008; Painter, Qian 2015), when culture may contribute to the investor's preferences of certain stocks (Grinblatt, Keloharju 2001). Thus, cultural differences can strongly affect the assets allocation within a portfolio (Guiso et al. 2006; Shyng et al. 2010).

The main dimensions of culture, discussed by economists, are beliefs (priors) and values (preferences) (Zingales 2015). People's cultural perceptions, acquired tastes, and values that affect their economic behavior are called habitus (Bourdieu 1986). The most elementary economic behaviors (working for a wage, savings, credit, etc.) are not axiomatic in various societies (Bourdieu 2000). Thus, economic habitus can differ and be strongly affected by culture. Bourdieu explained the economic behavior of persons in pre-capitalist economies, but he was never interested in the differences in economic behavior between immigrant and native populations. Most modern studies that examine determinants of investors' financial behavior do not overlap with migration studies.

This paper aims to fill this gap by investigating the modes of financial behavior of immigrants, comparing them with native-born investors. Particular attention is paid to creating a framework for analyzing financial behavior modes for immigrant and native-born investors, and examining the determinants of choosing a certain mode. More specifically, the objectives of this study are:

- To map the modes of financial behavior based on the risk preferences of immigrants and native-born persons.

- To examine the differences in portfolio risk and assets allocation between immigrant and native-born populations. 
- To determine the factors that affect choice of a mode of financial behavior among immigrants and native-born persons.

- To investigate the profiles of investors who choose particular modes of financial behavior, and to examine similarities and differences in these profiles between immigrant and native-born investors.

According to Bourdieu (1986), capital can be presented in three basic guises: economic (money and financial assets), cultural (cultural goods and long-lasting dispositions), and social (derived from membership in a group). Many studies stress the differences in the economic and social capital of immigrants and native-born persons just after immigration (Chatterjee, Zahirovic-Herbert 2012; Heilbrunn, Kushnirovich 2015; Osili, Paulson 2006). Some of them indicate the evidence for differences in financial behavior and financial assets portfolio allocation between immigrant and native-born populations. Immigrants in general have little financial assets (Chatterjee, Zahirovic-Herbert 2012; Choe et al. 2010; Osili, Paulson 2014), and are less likely to participate in financial markets than native-born people are (Chatterjee 2009; Keloharju, Lehtinen 2015; Osili, Paulson 2006). This may be explained by the fact that immigrants have restricted access to information about financial markets in the host country (Karunarathne, Gibson 2014; Kushnirovich 2011; Seto, Bogan 2013). Although immigrants are typically considered a self-selected group of individuals who are willing to undertake risks (Borjas et al. 1992; Jaeger et al. 2007), Bonin et al. (2009) found that immigrants in host countries were more risk averse than the native population. Immigrants' risk tolerance may be affected by social norms in the sending country (Bauer et al. 2011; Fang et al. 2013). According to the New Economics of Labor Migration theory, migration is seen as a risk-diversifying strategy (Amuedo-Dorantes, Pozo 2013), which suggests that immigrants would be negatively selected by their risk tolerance. In sum, immigrants' attitudes to risk differ from those of the native-born population (Amuedo-Dorantes, Pozo 2010; Chatterjee 2009), their earnings are lower (Chiswick, Miller 2007; Borjas, Friedberg 2009), and they have less opportunities for savings (Fausten et al. 2009; Sinning 2007). The cultural and social norms of the country of origin shape immigrants' economic habitus. Therefore, their choice of portfolio should differ from that of native-born investors.

\section{Framework for analyzing determinants of financial behavior modes of immigrants}

The mode of the investor's financial behavior should be affected by the investors' economic, cultural and social capital expressed in objective and subjective attributes. Since economic, cultural and social capital of immigrants differ from those of the native-born population, their attributes also should be different, as should their preferences of a financial portfolio.

Portfolios are usually classified into three standard types: aggressive, conservative, and moderate, and they reflect the modes of financial behavior. Aggressive portfolios are high-risk and low-diversified; stocks constitute about 80-95 percent of them (Feldman, Roy 2004). Conservative investors generally prefer non-risky assets; their portfolios are also low-diversified (Bondt 1998). Moderate investors use a mix of various assets with 
different levels of risk; the risk of their portfolios is usually smaller than that of aggressive investors, but higher than that of conservative ones (Chhabra 2005; Shyng et al. 2010). Investors prefer a mode based on their economic, cultural, and social capital expressed in terms of their objective and subjective attributes. These attributes are the determinants of financial behavior modes.

The framework for analyzing determinants of financial behavior modes of immigrant and native-born investors (Table 1) is based on Bourdieu's theory of cultural capital and economic habitus, the theory of investor's attributes (Dorn, Huberman 2005), and the wealth allocation framework (Chhabra 2005), applying these theories to the case of portfolio choice by immigrant and native-born investors. Determinants are divided into classes: demographic characteristics and education, information and awareness, risk tolerance, income and savings. All determinants of a financial behavior mode are derived either from cultural perceptions of the country of origin, or from the fact of immigration itself (immigrant status).

Demographic characteristics and education are objective parameters rooted in the investors' origin. For immigrants, they reflect the cultural norms (habitus) as to acquisition education adopted in the sending country. Bourdieu considered educational qualifications as institutionalized terms of cultural capital through its conversion to economic capital. The second class of determinants, lack of information and awareness afflicting immigrants in the host country when language barriers and lack of social capital hinder collecting relevant information, is a subjective attribute derived from the fact of being an immigrant. Risk tolerance is affected by both social and cultural norms in the sending country (Bauer et al. 2011), and self-selection of immigrants as a group that is willing to undertake risks in order to migrate (Jaeger et al. 2007). Thus, risk tolerance is affected by both culture of origin and immigrant status. The last class of determinants - income and savings - includes objective attributes, which are a function of being an immigrant.

Table 1. The framework for analyzing determinants of financial behavior modes of immigrant and native-born investors

\begin{tabular}{lllll}
\hline & \multicolumn{3}{c}{ Existing theories } & \\
\cline { 2 - 4 } $\begin{array}{l}\text { The classes of } \\
\text { determinants }\end{array}$ & $\begin{array}{c}\text { Application of } \\
\text { Bourdieu's theory to } \\
\text { the case of financial } \\
\text { portfolio choice }\end{array}$ & $\begin{array}{c}\text { Theory of } \\
\text { investor's } \\
\text { attributes (Dorn, } \\
\text { Huberman 2005) }\end{array}$ & $\begin{array}{c}\text { Wealth allocation } \\
\text { framework } \\
\text { (Chhabra 2005) }\end{array}$ & The current study \\
\hline $\begin{array}{l}\text { Demographic } \\
\text { characteristics } \\
\text { and education }\end{array}$ & Cultural capital & $\begin{array}{l}\text { Objective } \\
\text { attributes }\end{array}$ & $\begin{array}{l}\text { Objective ability } \\
\text { to take risk }\end{array}$ & $\begin{array}{l}\text { Derived from the } \\
\text { culture of origin }\end{array}$ \\
\hline $\begin{array}{l}\text { Information } \\
\text { and awareness }\end{array}$ & Social capital & $\begin{array}{l}\text { Subjective } \\
\text { attributes }\end{array}$ & $\begin{array}{l}\text { Subjective desire } \\
\text { to avoid risk }\end{array}$ & $\begin{array}{l}\text { Derived from the } \\
\text { immigrant status }\end{array}$ \\
\hline Risk tolerance & Cultural capital & $\begin{array}{l}\text { Subjective } \\
\text { attributes }\end{array}$ & $\begin{array}{l}\text { Subjective desire } \\
\text { to avoid hrisk }\end{array}$ & $\begin{array}{l}\text { Derived from the } \\
\text { culture of origin and } \\
\text { immigrant status }\end{array}$ \\
\hline $\begin{array}{l}\text { Income and } \\
\text { savings }\end{array}$ & Economic capital & $\begin{array}{l}\text { Objective } \\
\text { attributes }\end{array}$ & $\begin{array}{l}\text { Objective ability } \\
\text { to take risk }\end{array}$ & $\begin{array}{l}\text { Derived from the } \\
\text { immigrant status }\end{array}$ \\
\hline
\end{tabular}




\section{Method}

\subsection{Data collection and demographics of the sample}

The data for this study was collected in 2010-2011 in Israel. This study focuses on immigrants from the Former Soviet Union (hereafter FSU) as the largest and most approachable group of immigrants ${ }^{1}$. Immigration to Israel is ethnic, only Jews or members of their families may immigrate and be granted citizenship. In spite of the ethnic character of immigration, for immigrants from the FSU, economic motives were very important in their decision to migrate (Amit 2010). This particular group of immigrants in Israel resembles other groups of immigrant citizens in the world, for whom economic and employment considerations are of great importance.

Combining convenient and snowball samples, 511 persons (255 FSU immigrants and 256 native-born Israelis) from 60 localities were surveyed via a comprehensive questionnaire. The characteristics of the sample are presented in Table 2. The gender and age distribution of both groups were rather equal. Immigrants were more educated than their native-born counterparts were, but they reported smaller incomes than native-born respondents did. Characteristics of the sample comply with national statistical data for FSU immigrants and native population (Kushnirovich 2013).

Table 2. Characteristics of the sample

\begin{tabular}{lccc}
\hline \multicolumn{1}{c}{ Characteristics } & $\begin{array}{c}\text { Immigrants } \\
\mathrm{N}=255\end{array}$ & $\begin{array}{c}\text { Native-born } \\
\mathrm{N}=256\end{array}$ & $\begin{array}{c}\text { Total } \\
\mathrm{N}=511\end{array}$ \\
\hline Female, \% & 46.0 & 45.5 & 45.8 \\
\hline Age, years & 38.1 & 35.8 & 37.0 \\
\hline Married, \% & 59.8 & 48.5 & 54.3 \\
\hline High education, \% & 51.6 & 43.5 & 47.7 \\
\hline $\begin{array}{l}\text { \% of households whose income is less than } \\
\text { the average income in Israel }\end{array}$ & 40.7 & 26.0 & 33.5 \\
\hline
\end{tabular}

\subsection{Measures}

Characteristics of portfolio. The most important characteristics of a portfolio are assets allocation and risk. In this study, the following groups of financial assets were delineated: stocks and mutual funds, corporate bonds, government bonds, short-term deposits, and checking accounts. The respondents were asked about the division of their current savings into these groups of assets. The risk was calculated based on the Modern Portfolio Theory as portfolio return variance, which is a function of the correlations of the component assets, for all asset pairs. In order to calculate return variance for each group

\footnotetext{
${ }^{1} \mathrm{FSU}$ immigrants comprise more than 80 percent of the immigrants who came to Israel since 1990.
} 
of financial assets, the data from the Stock Exchange in Tel Aviv were used (monthly returns over three years preceding the study) ${ }^{2}$.

Demographic characteristics and education variables were being immigrant $(1=\mathrm{im}-$ migrant); gender $(1=$ male); age in years; education in terms of credentials (categorized on a scale of $1-7)$; marital status $(1=$ married), and years since migration (is relevant only for immigrants).

Financial risk tolerance. The index of personal financial risk tolerance in financial decisions was created based on Nicholson et al. (2005) who examined financial risk in terms of gambling, and Dohmen et al. (2005) who used the question about lottery participation in order to measure risk preferences of individuals. In current study, the measure of financial risk tolerance is based on three questions concerning participation in a lottery, gambling online, and buying scratch cards, when the respondents were asked to evaluate their participation on a scale from " 1 " = "do not participate at all" to " $5 "=$ "regularly participate". The index of financial risk tolerance was calculated as the average score of all three items (the reliability coefficient Cronbach's Alpha $=0.785$ ).

Economic awareness. In order to determine economic awareness, a measure developed by Kushnirovich (2011) was used. This measure contains thirteen items on a scale of " 1 " to " 4 " that proved validity. The index of economic awareness was calculated as the average score of all thirteen items (Cronbach's Alpha $=0.870$ ).

Income and savings. Variables describing income and savings of respondents were income of household (on a scale of 1 to 5), propensity to save (percentage of income allocated to savings), having employer-funded advanced education fund (a form of savings fund with an opportunity to withdraw money once every 6 years), seniority of retirement program (measured in years), and investments in dwellings ( $1=$ own more than one dwelling, $0=$ own one dwelling or less).

\section{Results}

\subsection{Modes of investors' financial behavior}

In order to examine the differences in assets allocation between immigrant and nativeborn persons, a set of t-tests was run (Table 3 ). The study revealed significant differences in the shares of most kinds of financial assets. Immigrants were less likely to invest in stock and corporate bonds, relatively risky assets, and were more likely to hold their financial assets in checking accounts than native-born investors were. Immigrants were also less likely to hold their financial assets in short-term deposits than nativeborn population. Immigrants' portfolio risk was significantly lower than that of native investors, 2.0 versus 3.7 . These differences can be explained by the low familiarity of

\footnotetext{
${ }^{2}$ For stock returns, the data of TA-100 index comprising 100 leading stocks were used; for corporate bonds - the data on returns of the Tel-Bond Index, which comprises 20 leading corporative bonds; for government bonds - returns on bonds Galil (CPI-linked government bonds; the data on all series available in the market were used). The standard deviation (risk characteristic) of short-term deposits and checking accounts, which have very low levels of risk, was considered as striving to 0 .
} 
Table 3. Financial assets allocation of immigrant and native-born investors

\begin{tabular}{lcccc}
\hline \multicolumn{1}{c}{ Financial assets and risk } & Immigrants & Native-born & $t$-Test & $p$-Value \\
\hline Financial assets allocation, percentage: & & & & \\
\hline Stocks \& mutual funds & 12.8 & 19.7 & -12.1 & 0.001 \\
\hline Corporate bonds & 2.0 & 4.7 & -2.789 & 0.006 \\
\hline Government bonds & 4.7 & 5.6 & -0.657 & Non-significant \\
\hline Short-term deposits & 14.1 & 22.5 & -3.152 & 0.002 \\
\hline Checking accounts & 65.1 & 47.2 & 5.099 & 0.000 \\
\hline Portfolio risk & 2.0 & 3.7 & -2.189 & 0.029 \\
\hline
\end{tabular}

Note: In Israel, checking accounts are not interest-bearing assets; therefore, they were considered separately from short-term deposits. The total percentage of checking accounts and short-term deposits in immigrants' portfolios is 79.2 versus 69.7 for native-born investors $(t=3.251, \mathrm{p}<0.001)$.

immigrants with the financial market of the host country, and financial constraints and liquidity needs that are larger for new immigrants due to a greater need for countryspecific investments (housing, etc.).

In order to classify respondents by their financial behavior mode, hierarchical clustering analysis was used. All respondents were grouped by the shares of stocks and mutual funds, corporate bonds, government bonds, short-term deposits, checking accounts and portfolio risk. Hierarchical clustering analysis revealed that the optimal number of clusters should be three. Then, using a K-means cluster analysis, a non-hierarchical clustering algorithm was performed to divide the immigrants and native-born persons into three clusters. The contribution of each of the seven factors to the formation of the clusters was examined (Table 4). The study revealed that all seven portfolio characteristics contributed significantly ( $p$-Value $<0.001)$ to the formation of the three clusters. Table 4 shows that each cluster is characterized by a different combination of assets allocation and risk, namely, a different mode of financial behavior.

Investors in the first cluster hold about 83 percent of their assets in stocks; therefore, they are called "Preferring risk". This pattern corresponds with the "Aggressive investor" type described in the previous sections, according to which about 85-90 percent of the portfolio is invested in stocks, relatively risky assets. Correspondingly, the portfolio risk of "Preferring risk" investors is significantly higher than that of other types of investors (28.7 for immigrants and 32.3 for native-born investors). The second cluster consists of "Preferring liquidity" persons who hold almost all assets in short-term deposits and checking accounts. This cluster is associated with behavior of "Conservative investors" who generally seek to protect their savings from risk by placing them in low risk investments despite low expected returns. The share of short-term deposits and checking accounts comprises about 96 percent of the portfolio of "Preferring liquidity" immigrant investors and 97 percent of the portfolio of native-born investors. The investors in the third cluster "Diversifying assets" are willing to divide their savings among different types of assets. They invested about 10-30 percent in each kind of asset, that 
Table 4. Investors' financial behavior modes (final centers of the clusters by financial assets allocation and portfolio risk)

\begin{tabular}{lcccccc}
\hline & \multicolumn{5}{c}{ Clusters of financial behavior modes } \\
\cline { 2 - 7 } Portfolio characteristics & \multicolumn{2}{c}{ Preferring risk } & Preferring liquidity & \multicolumn{2}{c}{ Diversifying assets } \\
\cline { 2 - 7 } & Aggressive investors & Moderate investors & Conservative investors \\
\cline { 2 - 7 } & Imm. & Native & Imm. & Native & Imm. & Native \\
\hline $\begin{array}{l}\text { Financial assets allocation, } \\
\text { percentage: }\end{array}$ & $100 \%$ & $100 \%$ & $100 \%$ & $100 \%$ & $100 \%$ & $100 \%$ \\
\hline Stocks \& mutual funds & 82.8 & 82.6 & 43.3 & 41.8 & 2.2 & 2.2 \\
\hline Corporate bonds & 1.4 & 1.3 & 12.0 & 17.2 & 0.1 & 0.1 \\
\hline Government bonds & 1.4 & 3.0 & 22.8 & 19.1 & 1.4 & 0.5 \\
\hline Short-term deposits & 7.9 & 2.3 & 7.1 & 8.2 & 16.0 & 31.2 \\
\hline Checking accounts & 6.4 & 10.8 & 14.3 & 13.1 & 80.3 & 66.0 \\
\hline Portfolio risk & 28.7 & 32.3 & 2.0 & 3.0 & 0.2 & 0.10 \\
\hline
\end{tabular}

Note: The study found significant differences between the clusters $(\mathrm{p}<0.001)$ for each group of assets and risk; there were no differences in assets allocation and risk between immigrant and native-born investors who belonged to the same cluster.

should reduce the portfolio risk and provide sufficient expected returns. Their behavior is very similar to the behavior of "Moderate investors" who generally use a diversified mix of investments to achieve higher returns, and take on more investment risk than conservative investors do. Thus, clusters found in this study empirically by means of cluster analysis are strongly associated with the three types of investors well known in the literature. Accordingly, each cluster expresses a different mode of financial behavior.

Although portfolio characteristics of immigrant and native-born investors who belonged to the same cluster were rather similar, there were differences in the distribution of investors between the clusters. Immigrants were overrepresented in the second cluster, "Preferring liquidity", holding their liquid current assets in short-term deposits or current accounts (77.6 percent of immigrants), namely, most of them were conservative investors. However, they were underrepresented in the first and third clusters: only 5.4 percent of them were in the "Preferring risk" cluster (aggressive investors) and 17.0 percent of them were in the "Diversifying assets" cluster (moderate investors). The distribution of native-born Israelis among the clusters was as follows: 8.9 percent in the cluster "Preferring risk", 64.5 percent in the cluster "Preferring liquidity", and 26.6 percent in the "Diversifying assets" cluster. Immigrants were less likely to invest in risky assets, but also were less likely to diversify their assets than the Israeli-born population was.

\subsection{Determinants of investors' financial behavior modes}

In order to examine which factors affect investors' mode of financial behavior, multinomial logit regressions were run for immigrants and native-born persons separately. The dependent variable was mode of financial behavior (categorical variable), whereas 
"Diversifying assets" (moderate investors) was the reference group. Both regressions were found to be significant, and described about 50 per cent of the variance in the dependent variable (see Table 5).

The study revealed that immigrant men were more likely to be aggressive investors (preferring risk) than women were. Married immigrants avoided risk. Education was a significant factor for reducing preferences for either risk or liquidity, meaning that the most educated immigrants preferred the reference group "Diversifying assets". Investing in real estate is associated among immigrants with being an aggressive investor. Being a conservative investor (preferring liquidity) is associated with low economic awareness, low propensity to save, not having an employer-funded advanced education fund, and shorter duration of living in the host country. Among native-born investors, income negatively predicted the "Preferring liquidity" mode. Low economic awareness was associated with preferring liquidity, and high awareness contributed to preferring risk.

Table 5. The results of multinomial logit regressions

\begin{tabular}{|c|c|c|c|c|c|c|c|c|}
\hline \multirow{3}{*}{ Determinants } & \multicolumn{4}{|c|}{ Immigrants } & \multicolumn{4}{|c|}{ Native-born persons } \\
\hline & \multicolumn{2}{|c|}{ Preferring risk } & \multicolumn{2}{|c|}{ Preferring liquidity } & \multicolumn{2}{|c|}{ Preferring risk } & \multicolumn{2}{|c|}{ Preferring liquidity } \\
\hline & B & $\operatorname{Exp}(B)$ & B & $\operatorname{Exp}(B)$ & B & $\operatorname{Exp}(B)$ & B & $\operatorname{Exp}(B)$ \\
\hline Gender & $2.703 * *$ & 14.918 & -0.394 & 0.674 & 1.173 & 3.231 & -0.012 & 0.988 \\
\hline Age & 0.090 & 1.094 & -0.020 & 0.980 & -0.108 & 0.897 & -0.042 & 0.959 \\
\hline Marital status & $-3.456^{* *}$ & 0.032 & 0.536 & 1.709 & -0.368 & 0.692 & 0.307 & 1.359 \\
\hline Education & $-1.567 * * *$ & 0.209 & $-0.706 * * *$ & 0.493 & 0.189 & 1.208 & 0.135 & 1.144 \\
\hline Awareness & 0.554 & 1.741 & $-0.831 * *$ & 0.436 & $2.296^{* *}$ & 9.936 & $-0.857 *$ & 0.424 \\
\hline $\begin{array}{l}\text { Financial risk } \\
\text { tolerance }\end{array}$ & $1.337 * *$ & 3.809 & $-0.812 * *$ & 0.444 & $0.639 * *$ & 1.894 & -0.284 & 0.753 \\
\hline $\begin{array}{l}\text { Income of } \\
\text { household }\end{array}$ & -0.962 & 0.382 & -0.163 & 0.849 & 0.327 & 1.387 & $-0.628 * * *$ & 0.534 \\
\hline $\begin{array}{l}\text { Propensity to } \\
\text { save }\end{array}$ & 0.043 & 1.044 & $-0.027^{*}$ & 0.973 & $-0.056^{* *}$ & 0.946 & -0.006 & 0.994 \\
\hline $\begin{array}{l}\text { Seniority of } \\
\text { retirement } \\
\text { program }\end{array}$ & -0.084 & 0.919 & 0.071 & 1.074 & $0.140^{*}$ & 1.150 & -0.010 & 0.990 \\
\hline $\begin{array}{l}\text { Having } \\
\text { employer- } \\
\text { funded advanced } \\
\text { education fund }\end{array}$ & 0.533 & 1.704 & $-1.196^{* *}$ & 0.302 & -0.282 & 0.754 & -0.554 & 0.575 \\
\hline $\begin{array}{l}\text { Investments } \\
\text { in real estate } \\
\text { (dwellings) }\end{array}$ & $3.288^{*}$ & 26.781 & -0.376 & 0.686 & -0.214 & 0.808 & -0.671 & 0.511 \\
\hline YSM & 0.001 & 1.001 & $-0.065^{* *}$ & 0.937 & & & & \\
\hline Pseudo R square & $0.518 * * *$ & & & & $0.491 * * *$ & & & \\
\hline
\end{tabular}

Notes: The reference group is "Diversifying assets"; * $<<0.050 ; * * p<0.010$; ${ }^{* * *} p<0.001$ 
Seniority of retirement insurance positively predicted preferring risk, and propensity to save negatively predicted it. Financial risk tolerance reduced the chance to be a conservative investor preferring liquidity and increased chances to prefer risky assets among immigrant investors. Among the native-born investors, risk tolerance is associated with preferring liquidity.

The study found that duration of living in the host country is a significant predictor of immigrants' choice of a mode of financial behavior. The longer the immigrant has lived in the host country, the smaller the likelihood that s/he would prefer liquidity or, in other words, the higher the likelihood that the immigrant would hold more risky assets. Longer experience in the host country implies acculturation and economic integration of immigrants. Figure 1 shows the distribution of immigrants among the modes of financial behavior by year since migration, comparing them with the native-born population. In the first ten years, immigrants' financial behavior differs from that of native-born investors: only five percent of immigrants diversify assets and they prefer not to take a risk. After ten years, the differences come to naught. With the increasing number of years, immigrants began to diversify their assets. The share of immigrants who prefer a risky mode also increases over time and even exceeds that of native-born investors. Distribution of immigrants who have lived in the host country thirty years and more by modes of financial behavior is almost the same as that of the native-born population. Thus, over time immigrants assimilate in their financial choices.

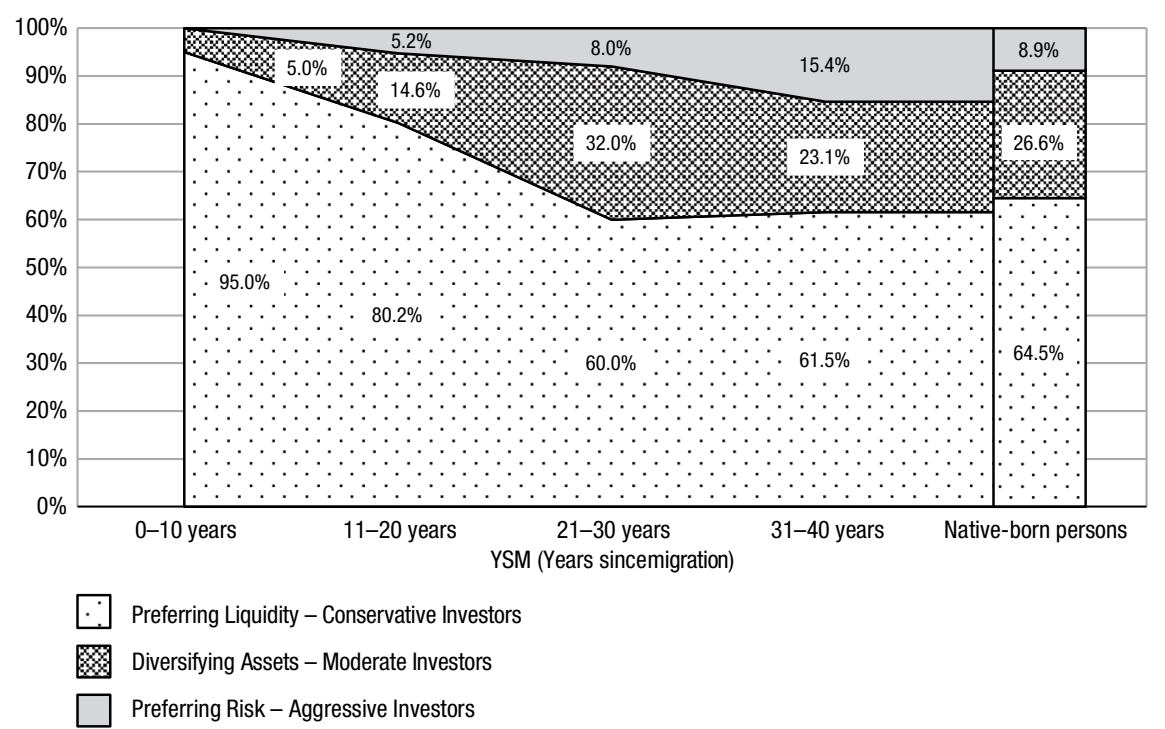

Fig. 1. Distribution of immigrant and native-born investors between the modes of financial behavior, by YSM 


\subsection{Features of investors by modes}

The study revealed that the traits of investors by modes are different for immigrant and native-born populations (Table 6). The most economically poor group of immigrants tends to hold the most risky assets. The respondents in the cluster "Preferring risk", who mostly hold stock, were predominantly low-educated single men with low income, the lowest ownership rate of an employer-funded advanced education fund, and the shortest seniority of pension insurance. In spite of their poor financial resources, they reported the highest share of savings and were the most likely to invest in dwellings, namely, they demonstrated high propensity to save.

Table 6. Characteristics of immigrant and native-born investors by the mode of financial behavior

\begin{tabular}{lcccccccc}
\hline \multirow{2}{*}{ Characteristics } & \multicolumn{4}{c}{ Immigrants } & \multicolumn{4}{c}{ Native-born persons } \\
\cline { 2 - 9 } & PR & PL & DA & Test & PR & PL & DA & Test \\
\hline Female, \% & 21.4 & 47.3 & 40.9 & $\mathrm{~F}=6.0^{*}$ & 18.2 & 49.7 & 37.7 & $\chi^{2}=9.2^{* *}$ \\
\hline Age, years & 34.3 & 38.2 & 41.4 & $\chi^{2}=0.1$ & 38.1 & 33.5 & 40.0 & $\mathrm{~F}=7.2^{* * *}$ \\
\hline Married, \% & 25.0 & 61.6 & 71.1 & $\chi^{2}=8.2^{* *}$ & 47.8 & 40.4 & 61.0 & $\chi^{2}=7.2^{*}$ \\
\hline High education, \% & 28.6 & 49.8 & 72.7 & $\chi^{2}=11.0^{* *}$ & 47.8 & 37.8 & 50.0 & $\chi^{2}=3.3$ \\
\hline Awareness & 3.0 & 2.7 & 3.0 & $\mathrm{~F}=3.8^{* *}$ & 3.5 & 2.9 & 3.3 & $\mathrm{~F}=16.0^{* * *}$ \\
\hline Financial risk tolerance & 3.0 & 2.5 & 2.8 & $\mathrm{~F}=3.8^{*}$ & 3.3 & 2.3 & 2.8 & $\mathrm{~F}=2.0^{* * *}$ \\
\hline Income of household & 2.4 & 2.9 & 3.3 & $\mathrm{~F}=2.3$ & 4.0 & 3.0 & 4.0 & $\mathrm{~F}=17.3^{* * *}$ \\
\hline Propensity to save, \% & 41.7 & 20.2 & 26.1 & $\mathrm{~F}=7.8^{* * *}$ & 20.3 & 23.6 & 29.3 & $\mathrm{~F}=2.2$ \\
\hline $\begin{array}{l}\text { Seniority of retirement } \\
\text { program, years }\end{array}$ & 6.0 & 7.8 & 9.6 & $\mathrm{~F}=1.3$ & 13.1 & 7.0 & 13.6 & $\mathrm{~F}=12.1^{* * *}$ \\
\hline $\begin{array}{l}\text { Having employer-funded } \\
\text { advanced education fund, \% }\end{array}$ & 28.6 & 33.0 & 56.8 & $\chi^{2}=9.2^{* *}$ & 65.2 & 39.5 & 63.8 & $\chi^{2}=14.4^{* *}$ \\
\hline $\begin{array}{l}\text { Investments in real estate } \\
\text { (dwellings), \% }\end{array}$ & 21.4 & 10.4 & 13.6 & $\chi^{2}=1.8$ & 22.7 & 3.0 & 23.9 & $\chi^{2}=26.8^{* * *}$ \\
\hline Years since migration & 20.6 & 16.7 & 22.1 & $\mathrm{~F}=8.4^{* * *}$ & & & & \\
\hline
\end{tabular}

Notes: $* p<0.050 ; * * p<0.010 ; * * * p<0.001$.

High-educated immigrants tend to diversify their assets, owning a wide range of financial assets ("Diversifying assets" mode). The respondents in this cluster were the oldest, high-income, married persons, and included both men and women. They are characterized by the highest long-term savings: the longest seniority of pension insurance, and the largest share of holders of employer-funded advanced education funds. Their current propensity to save and financial risk tolerance were at the middle level.

In contrast to immigrants, the poorest Israehli-born persons keep their money in shortterm deposits or in current accounts with no risks. The members of this group are loweducated, their income is the lowest, they are not likely to own dwellings for investment purposes, and they reported the shortest seniority of retirement programs. Only 39.5 percent of them (the lowest percent) have an advanced education fund. They are also less aware of the economic and financial situation than their counterparts in other 
clusters are. Thus, they are a relatively young, low-income population with no possibility to save considerable sums. Israeli-born respondents who prefer to invest in stock are highly educated, and have the highest economic and financial awareness. They are a high-income group with considerable long-term savings (65.2 percent of them have employer-funded advanced education fund, and 22.7 percent of them invested in dwellings), but their current propensity for saving is relatively low. This group predominantly consists of men with high financial risk tolerance.

In spite of the differences in economic status of immigrants and native-born investors, the characteristics of the immigrants in the third cluster "Diversifying assets" were rather similar to those of their native-born counterparts. Though the income and the percent of education fund holders among immigrants in this cluster were slightly lower than those of their Israeli counterparts, they were still high compared to other groups of immigrants. Some characteristics of immigrants and native Israelis in this cluster were almost the same (age, percent of females, financial risk tolerance, etc.).

\section{Conclusions}

This paper provides an analysis of the financial behavior modes of immigrant and native-born populations, investigating the determinants of choosing a certain mode. The modes of financial behavior are defined in terms of portfolio risk and financial assets allocation. The study revealed that immigrants were less likely to invest in risky assets, and less likely to diversify their assets, than native-born investors were. Correspondingly, the risk of immigrants' portfolios was significantly lower than that of their native counterparts.

Based on the developed theoretical framework, the study examined the determinants of financial behavior modes. For immigrants, demographic characteristics and education derived from the culture of origin were significant predictors of their financial behavior mode. Economic capital, financial risk tolerance, and economic awareness were significant predictors for both immigrant and native-born investors. Economic capital and awareness derive from the fact of being an immigrant (for immigrants) or reflect the advantage of being native-born (for native investors). Risk tolerance derives from culture of origin or immigrant status. Thus, an investor's behavior mode is strongly predicted by determinants derived not only from economic and social capital that are widely discussed in the economic literature, but also from cultural capital.

The study also revealed that over time immigrants assimilate in their choice of financial mode. On the one hand, increasing similarity of natives and immigrants could very well be evidence for acculturation in financial behavior. However, equally plausible explanations exist. Financial constraints and liquidity needs could be larger in the early years since migration. With increasing time of residence, the need for liquidity decreases. Although the empirical analysis lacks the power to distinguish between acculturation and economic integration, the study conclusively revealed assimilation of immigrants in their financial behavior.

The study determined profiles of investors preferring different modes of financial behavior. It revealed that young, low-educated and low-income immigrants preferred risky as- 
sets, investing in stock, whereas the same category of Israeli-born respondents preferred liquid assets, holding their current assets in short-term deposits or checking accounts. The high-educated, high-income and highly aware investors, both immigrants and native Israelis, preferred to diversify their assets. Thus, high-educated and high-income immigrants were rather similar to their Israeli counterparts. This similarity exists despite the ongoing differences in economic status, namely that the income and long-term savings of skilled immigrants were still lower than those of Israeli-born skilled individuals. In sum, the study found that the financial behavior of low-income persons (immigrant and nativeborn) was different, and behavior of high-income persons was similar. It seems that for low-income persons the culture of origin shapes their financial behavior, and for highincome persons, their economic capital and affiliation to social class are more important.

This study has some policy implications. Portfolio choices eventually have an impact on the rate at which wealth is accumulated, when wealth is a very important characteristic of immigrants' economic integration, and consequently, their social integration. Understanding migrants' modes of financial behavior and its determinants will help policymakers to facilitate accumulation of wealth by immigrants, and in this way contribute to the process of immigrants' integration.

This study has some limitations. Since only immigrants from the FSU in Israel were examined, it was impossible to investigate differences in financial behavior between immigrants of different origin, and examine how cultural capital and ethnic background affect portfolio choice after controlling the effect of immigration. Subsequent studies should be performed in this field.

\section{References}

Ahern, K. R.; Daminelli, D.; Fracassi, C. 2015. Lost in translation? The effect of cultural values on mergers around the world, Journal of Financial Economics 117(1): 165-189.

http://dx.doi.org/10.1016/j.jfineco.2012.08.006

Amit, K. 2010. Determinants of life satisfaction among immigrants from Western countries and from the FSU in Israel, Social Indicators Research 96(3): 515-534.

http://dx.doi.org/10.1007/s11205-009-9490-1

Amuedo-Dorantes, C.; Pozo, S. 2010. International remittances and migrant portfolio interests, in Latin American and Caribbean Economics Association Annual Meetings, 11 November, 2010, Medellin, Colombia.

Amuedo-Dorantes, C.; Pozo, S. 2013. Remittances and portfolio values: an inquiry using immigrants from Africa, Europe, and the Americas, World Development 41: 83-95.

http://dx.doi.org/10.1016/j.worlddev.2012.05.036

Bauer, T. K.; Cobb-Clark, D. A.; Hildebrand, V. A.; Sinning, M. G. 2011. A comparative analysis of the nativity wealth gap, Economic Inquiry 49(4): 989-1007.

http://dx.doi.org/10.1111/j.1465-7295.2009.00221.x

Bondt, W. 1998. Behavioural economics. A portrait of the individual investor, European Economic Review 42: 831-844. http://dx.doi.org/10.1016/S0014-2921(98)00009-9

Bonin, H.; Constant, A.; Tatsiramos, K.; Zimmermann, K. F. 2009. Native-migrant differences in risk attitudes, Applied Economics Letters 16(15): 1581-1586.

http://dx.doi.org/10.1080/13504850701578926

Borjas, G.; Bronars, S.; Trejo, S. 1992. Self-selection and internal migration in the United States, Journal of Urban Economics 32(2): 159-185. http://dx.doi.org/10.1016/0094-1190(92)90003-4 
Borjas, G. J.; Friedberg, R. M. 2009. Recent trends in the earnings of new immigrants to the United States. Working paper 15406. National Bureau of Economic Research.

Bourdieu, P. 1986. The forms of capital, in J.G. Richarson (Ed.). Handbook of theory and research for the sociology of education. New York: Greewood Press.

Bourdieu, P. 2000. Making the economic habitus, Ethnography 1(1): 17-41.

http://dx.doi.org/10.1177/14661380022230624

Chhabra, A. B. 2005. Beyond Markowitz: a comprehensive wealth allocation framework for individual investors, The Journal of Wealth Management 7(4): 8-34.

http://dx.doi.org/10.3905/jwm.2005.470606

Chatterjee, S. 2009. Individual stockownership in the United States: native-immigrant gap and the role of risk tolerance, International Research Journal of Finance and Economics 28: 160-168.

Chatterjee, S.; Zahirovic-Herbert, V. 2012. A road to assimilation: immigrants and financial markets, Journal of Economics and Finance 38(2): 345-358.

http://dx.doi.org/10.1007/s12197-011-9224-5

Chiswick, B. R.; Miller, P. W. 2007. Matching language proficiency to occupation: the effect on immigrants' earnings. Discussion paper 2587. Institute for the Study of Labor (IZA), Bonn.

Choe, C.; Hildebrand, V.A.; Sierminska, E. 2010. Immigrants, assimilation and wealth portfolios, in 31st General Conference of the International Association for Research in Income and Wealth, 22-28 August 2010, St-Gallen, Switzerland.

Cobb-Clark, D. A.; Hildebrand, V. A. 2009. The asset portfolios of native-born and foreign-born Australian households, The Economic Record 85(268): 46-59.

http://dx.doi.org/10.1111/j.1475-4932.2008.00528.x

Dohmen, T.; Falk, A.; Huffman, D.; Sunde, U.; Schupp, J.; Wagner, G. G. 2005. Individual risk attitudes: new evidence from a large, representative, experimentally-validated survey. Discussion paper 1730. Institute for the Study of Labor (IZA), Bonn.

Dorn, D.; Huberman, G. 2005. Talk and action: what individual investors say and what they do, Review of Finance 9: 437-481. http://dx.doi.org/10.1007/s10679-005-4997-z

Fang, M. C.; Hanna, S. D.; Chatterjee, S. 2013. The impact of immigrant status and racial/ethnic group on differences in responses to a risk aversion measure, Journal of Financial Counseling and Planning 24(2): 63-76.

Fausten, D.; Islam, A.; Parasnis, J. 2009. Disparity between immigrant and native saving behaviour in Australia. Monash Economics Working paper 27-10. Monash University, Monash.

Feldman, B. E.; Roy, D. 2004. Passive options-based investment strategies: the case of the CBOE S\&P 500 buy write index, ETF and Indexing 1: 72-89.

Grinblatt, M.; Keloharju, M. 2001. How distance, language, and culture influence stockholdings and trades, The Journal of Finance LVI (3): 1053-1073.

http://dx.doi.org/10.1111/0022-1082.00355

Guiso, L.; Sapienza, P.; Zingales, L. 2006. Does culture affect economic outcomes?, Journal of Economic Perspectives 20, 23-48. http://dx.doi.org/10.1257/jep.20.2.23

Guiso, L.; Sapienza, P.; Zingales, L. 2008. Trusting the stock market, Journal of Finance 63(6): 2557-2600. http://dx.doi.org/10.1111/j.1540-6261.2008.01408.x

Heilbrunn, S.; Kushnirovich, N. 2015. Entrepreneurial finance of minority and migrant groups in Israel, Chapter 10 in J. G. Hussain, J. M. Scott (Eds.). International research handbook on entrepreneurial finance. Cheltenham, Northampton: Edward Elgar.

http://dx.doi.org/10.4337/9781783478798.00016

Jaeger, D. A.; Falk, A.; Bonin, H.; Huffman, D.; Dohmen, T.; Sunde, U. 2007. Direct evidence on risk attitudes and migration. Discussion paper 2655. Institute for the Study of Labour (IZA), Bonn. 
Karunarathne, W.; Gibson, J. 2014. Financial literacy and remittance behavior of skilled and unskilled immigrant groups in Australia, Journal of Asian Economics 30: 54-62.

http://dx.doi.org/10.1016/j.asieco.2013.12.004

Keloharju, M.; Knupfer, S.; Rantapuska, E. 2012. Mutual fund and share ownership in Finland, Liiketaloudellinen aikakauskirja 2: 178-198.

Keloharju, M.; Lehtinen, A. 2015. Shareownership in Finland. Working paper. Aalto University, Helsinki.

Kim, J.; Chatterjee, S.; Cho, S. H. 2012. Asset ownership of new Asian immigrants in the United States, Journal of Family and Economic Issues 33: 215-226.

http://dx.doi.org/10.1007/s10834-012-9317-0

Kushnirovich, N. 2011. Determinants of personal economic awareness, Economic Herald of the Donbas 4(26): 98-105.

Kushnirovich, N. (Ed.). 2013. Ruppin yearbook on immigration. Emek Hefer: Ruppin Academic Center, Institute for Immigration and Social Integration.

Nicholson, N.; Soane, E.; Fenton-O'Creevy, M. 2005. Personality and domain-specific risk taking, Journal of Risk Research 8 (2): 157-176. http://dx.doi.org/10.1080/1366987032000123856

Osili, U. O.; Paulson, A. 2006. Immigrant-native differences in financial market participation. Working paper 2004-18. Federal Reserve Bank of Chicago, Chicago.

Osili, U. O.; Paulson, A. 2014. Crises and confidence: systemic banking crises and depositor behavior, Journal of Financial Economics 111(3): 646-660.

https://doi.org/10.1016/j.jfineco.2013.11.002

Painter, M. A.; Qian, Z. 2015. Wealth inequality among new immigrants, Sociological Perspectives 58(3): 1-27.

Pevzner, M.; Xie, F.; Xin, X. 2015. When firms talk, do investors listen? The role of trust in stock market reactions to corporate earnings announcements, Journal of Financial Economics 117(1):190-223. http://dx.doi.org/10.1016/j.jfineco.2013.08.004

Seto, S.; Bogan, V. L. 2013. Immigrant household investment behavior and country of origin: a study of immigrants to the United States, International Journal of Finance and Economics 18: 128-158. http://dx.doi.org/10.1002/ijfe.464

Sinning, M. 2007. Wealth and asset holdings of immigrants in Germany. Discussion paper 3089. Institute for the Study of Labour (IZA), Bonn.

Shyng, J. Y.; Shieh, H. M.; Tzeng, G. H.; Hsieh, S. H. 2010. Using FSBT technique with Rough Set Theory for personal investment portfolio analysis, European Journal of Operational Research 201: 601-607. http://dx.doi.org/10.1016/j.ejor.2009.03.031

Zingales, L. 2015. The "cultural revolution" in finance, Journal of Financial Economics 117(1): 1-4. http://dx.doi.org/10.1016/j.jfineco.2015.05.006

Nonna KUSHNIROVICH, PhD, is a Senior Lecturer at the Department of Economics and Management and a Head of the Economic Studies for Non-Economists at the School of Economics and Business Administration, Ruppin Academic Center (Israel). She is also a Researcher at the Institute of Immigration and Social Integration. Nonna Kushnirovich received her PhD in 1993 at the Institute of Industrial Economics of the Ukrainian Academy of Science. Nonna is an Editor in Chief of the Yearbook on Immigration in Israel. She has published several academic articles, book chapters and two edited books. In 2010 she was included in the list of 100 Outstanding Immigrant Scientists in Israel. She is a member of the editorial boards of two academic journals. Dr Nonna Kushnirovich has a substantial experience in research projects; in 2005-2015 she was a principal investigator/coordinator of 10 research projects. Her current research interests include economics of immigration, immigrant entrepreneurship and labor migration. 